\title{
REVIVING PROPHET'S SPORT TRADITION IN MODERN DAY INDONESIA: DOES "FOLLOW THE PROPHET" MEAN RADICAL?
}

\author{
Mohamad Sobirin \\ State Islamic University (UIN) UIN Walisongo Semarang \\ mohamadsobirin@walisongo.ac.id/msobirin.sahal@gmail.com
}

\begin{abstract}
Muhammad as a prophet has given a wide range of inspiring life to Muslims through the traditions which he created; then these were recorded by canonical books of the Hadith. It was sport among the traditions. In a Hadith narrated by Ibn Umar, there are three kinds of exercise were ordered by the Prophet in which he said: "Teach your children swimming, archery and horse riding." In Sahih Muslim, the Prophet said, "Practice archery and horseback riding." The third sport performed by the Prophet is attractive to be reviewed, not because of its advantages for the health as claimed scientifically by some people, but due to the existing efforts to revive these Prophet's sports traditions by some Muslim communities in Indonesia.

This study aims to answer some questions, what are the factors having a role in motivating some Muslim communities in Indonesia to relive the Prophet's sports tradition? What do they take a look at modern sports? What does the revival look like and is there any relationship between the practices of reviving the Prophet's sports tradition and radicalism?

This research focuses on three based boarding school (pesantren)-Islamic schools, two of them are in Surakarta; Isy Karima and Al-Mu'min and one is in Semarang; Robby Radliya. The schools are private Islamic schools which require every student to join in extra-curricular activities, i.e., the Prophet's sports tradition and do not provide for other sports. By interviewing school principals and observing the objects qualitatively as well as approaching the study by Living Hadith theory, this research found that; a. Theological motif and health pseudo-orientation are the main factors contributing to succeed the effort of "follow the Prophet" in reviving the Prophet's sports tradition; 2. The prophetic sports are taught and implemented through the educational process; and 3. There is a relative relationship between those Indonesian Muslim communities who revive the Prophet's sports tradition and Islamism which tend to be radical.
\end{abstract}

Keywords: Prophet's Sport Tradition, Islamism, Living Hadith, Indonesian Muslim

\section{Introduction}

Exercise initially is a physical activity performed by someone with the aim to maintain health and improve body fitness. There are many sports activities to achieve these goals of healthy and fit, that is why there are many different kinds of sports. The Olympics in 2016 has opened 28 athletics to compete internationally. The truly and strangely compelling one is not benefits of the physical activities that can maintain the health and fitness of body or the victory achieved in the international event of competed games, but the growing trend of exercise inspired by the Prophet Muhammad (archery, riding, and swimming) within some communities of Indonesian Muslims today.

Islam -through the Hadith of the Prophet Muhammad- commanded Muslims to teach their children three kinds of athletics; archery, swimming, and horse riding. These are the physical activity's tradition of the Prophet, so by exercising this style of 
prophet's pastime and teaching his children these three prophet's body's activity, a Muslim is entitled to have performed a form of "follow the prophet" or in Arabic "itba' as-sunnah."

In modern Indonesia, it appears that there are some Muslims who practice the prophet's sport. A famous Ustad had stunned the digital world of Indonesia for showing the action of his archery that he did inside of a mosque, as well as an Ustad of a dzikir council (majlis dzikir) that displays the picture of a racetrack where he often practices and trains his wife, sons, and daughters to horse riding.

The practice of this prophet's sport is unfortunately not only performed by the two above Ustad, in Solo, there are two Islamic private schools (boarding house school) that insert these the prophet sports as an extra-curricular activity that must be joined by all students without exception either male or female students. The revival toward prophet's tradition is also founded in a private Islamic school in Semarang. Even one of the two institutions stated that these prophetic exercises are not just an extracurricular activity but the foremost activity that is obligatory to join. These educational institutions are Isy Karima, Al-Mukmin and Robby Radliya.

Some of the academic literature that has done the study as this study is very rare, and so far I did not find it. While the research that covers Islam and sports can be found in several international journals as follows: 1. Importance of Physical Fitness in The Light of Seerat E Tayyibah, an article written by Muhammad Zaid Malik in Journal "Jihāt al-Islām" Vol .4 Sirah No. (July-December 2010 / January-June 2011) No 1, 2. This article describes the prophetic teachings related to the importance of one's physical health and fitness. Elaboration is by presenting the views of Muslim scholar (ulama') about fitness and eating habits. 2. Sport, Physical Education, and Islam: Muslim Independent Schooling and the Social Construction of Masculinities, in "Sociology of Sport Journal" written by Samaya Farooq and Andrew Parker, (2009), 26, 277-295. This study highlights how religion provides a mechanism that serves to negotiate the existence of students with masculinity as a cultural formation through physical education practice. Furthermore, physical education becomes closely related to the broad religious ideals.

Another interesting study is the research that interconnecting sports with Muslim women, namely: 1. Sport Performance of Muslim Women and Different Constraints in Their Way to Participation in Sport, in "International Journal of Humanities and Social Science," Vol. 4, No. 10 (1); August 2014 "by Mohibullah Khan Marwat. The purpose of this study is to examine the various literature available on the performance of Muslim women in the sports arena and the special constraints that prevent them from engaging in a sport. 2. The Perspective of Arabic Muslim Women toward Sport Participation, written by Maesam-T-Abdul Razak in "Journal of Asia Pacific Studies", (2010) Vol 1, No. 2, 364-377. This study is intended to examine the point of view of Arab Muslim women of their involvement in sports and physical activity. The study used 15 samples of 14 to 30 year-old Arab Muslim women who "sojourn" in Malaysia. The writer's research position in the midst of pre-existing studies is more of a new variant of Islamic studies and sports.

This study aims to uncovering; what are the actual factors behind three Muslim communities (Isy Karima, Al-Mukmin and Robby Radliya) in practicing the prophet's exercise tradition? How did they exercise this prophet's sports in the process of teaching and learning? And is there any relationship between the practices of reviving the prophet's athletics with religious radicalism?

The general academic purpose of this study is to reveal the factors behind the practice of the revival toward the Prophet's sport tradition conducted by Indonesian 
Muslims, as well as to develop the Living Hadith study by interconnecting and integrating hadith studies and sociology or anthropology. Therefore, this study tries to interconnect the study of Living Hadith with the phenomenon of religious radicalism in Indonesia. While the academic benefit of this study is an offer of a new model of Living Hadith study that offers an interdisciplinary approach.

\section{Methods}

This study uses qualitative methods. I obtained primary data through interviews, observations, and document studies in which relevant to the study. I conducted interviews with school leaders: principals and representatives, as well as representative teachers (ustadz). I did observations on activities, places, and media used for prophetic sports, i.e., horses and racetrack, swimming and archery locations.

The interdisciplinary approach used in this study is living hadith and social psychology. Simply put, the Living Hadith here can be interpreted as a visible symptom in the community in the form of behavioral patterns derived from the Hadith of Prophet Muhammad. The behavior here is part of the Muslim response in their interactions with the traditions of the Prophet (Suryadilaga, 2005, 107-114). If there are three variants of Living Hadith; writing, oral and practice then the prophetic sport here including categories of variety of Living Hadith form of practice. This practice is an attempt to understand the Hadith-in this case the prophet's command to practice archery, horse riding and swimming-consciously, and then performing the Hadith as an attempt to apply the values contained in the Hadith. So when we may view it more deeply, the understanding gives an impact to a group of people with efforts to perform (Suryadilaga, 2005, 116-123).

Meanwhile, social psychology in this study has resulted a meaning that the aggressiveness of an individual or group behavior is proportional to the level of frustration experienced by the group or individual. Radicalism is different from aggressiveness, but in many ways, we see a correlation between the two. The democratic climate and freedom of association have a place since the government of Abdurrahman Wahid until now. This fact indicates that there is a radical ideological difference between the Soeharto era and post Abdurrahman Wahid. Frustration due to repressive action is no longer present. The radicalism occurs today more to the purification of Islam and partly the concept of religion and the State. Militarism and radicalism should be different from violence. Militants and radicals do not always violate the rules. Violence (terror) is the last alternative to a struggle or action of the losers (Koentjoro, 2009, 68-70).

\section{Result and Discussion}

The findings of this study indicate that the equestrian, swimming and archery exercises practiced in three pesantren-based schools in Solo and Semarang were inspired by the Prophet's command in several narrations of Hadith that they have known well and memorized, consciously. There are two different Hadith editors but the single meaning substance which is their theological ground in reviving the Prophet's sports tradition: "Teach your children to swim, archery and horse riding" and "Practice archery and horseback." Attempt to follow the "sunnah of the prophet" by practicing this prophetic sport is the biggest reason for the health and fitness motivation of the body.

They include this prophetic sporting activity as part of one of the learning pillars that aims to build or physical strength in Arabic "quwwah jasadiyyah". "If the physical is strong, then the body must be healthy," said Ustadz Ali Mursyidi, Headmaster of MATIQ Isy Karima and Headmaster MA Al-Mukmin and Ustadz Faqihuddin 
Headmaster of SMK Robby Rodliya. The physical strength here is meant to be a provision when entering into the arena of preaching religion ( $\left.d a^{\prime} w a h\right)$ that full of challenges and threats. That is why the portion of attention from school leaders and foundations is enormous for the sustainability of this program, so the infrastructure that supports it is built and prepared perfectly. Although for Al-Mukmin and Robbi Rodliya this activity is done by renting a swimming pool and racetrack of horse riding because of lack of adequate facilities. This sport is not only done by male students, but also by female students. In practice, there is a schedule that manages the time they have to practice this sport in turn and there is a coach who will accompany and guide them.

Listening to their narratives and opinions on the obligation of Jakarta and Indonesia to be led by a Muslim and the unlawful of choosing Ahok as Governor of Jakarta by Muslim, and looking at their efforts by sending their teachers and students to participate in the Peaceful Action of 212 (2016) in Jakarta and call for participation in the election of the governor of Jakarta for the Jakarta students showed that there are concerns in their minds regarding the political relationship between Muslims with nonMuslims in Indonesia. These dealings are of the reasons driving them to act so aggressively.

There are also other reasons in the global context such as Israel's control of AlAqsa Mosque, the US troop deployment in Syria-Iran and his military invasion in several Middle Eastern countries. As I quoted above, that the aggressiveness of a person or a group has a correlation with radicalism as well as concerns (in some degree frustrating) are directly proportional to aggression, so the practice of reviving the prophet's sport in the modern Indonesian context performed by those communities can be identified as a new form of militant symbol and radicalism. Although militancy and radicalism they embrace is not another form of violence that breaks the rules, or as the final form of a struggle (terrorism). Their combativeness and radicalism are synonymous of religious purification and attitudes to religious and state relations. Their militance and radicalism are also as a way of strengthening religious identity, considering their lack of support and the encouragement to other types of sports other than the prophetic exercise.

These findings, therefore, are very different from previous studies that portrayed sports with the normative approach of Islam or with a sociological one but left the context of phenomena related to Islamic doctrine (Al-Qur'an and Hadith). Muhammad Zaid Malik, Samaya Farooq, and Andrew Parker looks presented the exercise portraits based on the Islamic perspective. Although Farooq and Parker - unlike Zaid Malik - they succeeded in the Islamic normative approach integrated with education. While the portrait of sociological one is done by Mohibullah Khan Marwat and Maesam-T-Abdul Razak, with the subject of the study are Muslim women.

\section{Conclusions}

The factors motivating the three communities of Muslims in Solo and Semarang in practicing the sport of the prophet are religious factors that are legitimized by health and fitness reasons. The religious elements include firstly the prophetic traditions that become an inspiration, and secondly the religious militancy and radicalism which have a role as the fuel of the prophet's exercise practice. The practice of the prophet's sports in the Muslim community conducted systematically and integrated with the learning process has been able to make it a tradition and part of a new religious identity symbol attached to religious militancy and radicalism, although their militancy and religious radicalism are not synonymous with violent extremism.

New approaches are currently emerging; masculinity can be used as an alternative reading tool to the phenomenon of prophetic physical activity tradition 
practiced by several communities of Muslims in Indonesia. This new approach will yield significant and different findings because it may be the background of the practice of prophetic exercise is masculinity discourse. This masculinity will be more attractive when the subject of study is Muslim women.

\section{References}

Farooq, Samaya and Andrew Parker (2009). "Sport, Physical Education, and Islam: Muslim Independent Schooling and the Social Construction of Masculinities."Sociology of Sport Journal. Vol. 26, 277-295.

Koentjoro (2009). "Radikalisme Islam dan Perilaku Orang Kalah dalam Perspektif Psikologi Sosial". Psikobuana Vol. 1, No.1: 64-70.

Malik, Muhammad Zaid (2010/2011). "Importance of Physical Fitness in The Light of Seerat E Tayyibah". Jihāt al-Islām Vol.4 Sirah No. (July-December 2010/January-June 2011) No 1, 2.

Marwat, Mohibullah Khan (2014). "Sport Performance of Muslim Women and Different Constraints in Their Way to Participation in Sport." International Journal of Humanities and Social Science Vol. 4, No. 10 (1); August 2014.

Razak, Maesam-T-Abdul (2010). The Perspective of Arabic Muslim Women toward Sport Participation. Journal of Asia Pacific Studies Vol 1, No 2, 364-377.

Suryadilaga, M. Alfatih (2005). "Model-Model Living Hadis" dalam Sahiron Syamsuddin (ed), Metodologi Penelitian Living Qur'an dan Hadis. Yogyakarta: TH Press \& Teras 